\title{
Assessment of phenolic herbicide toxicity and mode of action by different assays
}

\author{
Cinzia Bettiol $^{1} \cdot$ Stefania De Vettori $^{1} \cdot$ Giovanni Minervini $^{2} \cdot$ Elisa Zuccon $^{1}$. \\ Davide Marchetto $^{3}$ - Annamaria Volpi Ghirardini ${ }^{4} \cdot$ Emanuele Argese $^{1}$
}

Received: 31 March 2015 / Accepted: 10 December 2015 /Published online: 23 December 2015

(C) Springer-Verlag Berlin Heidelberg 2015

\begin{abstract}
A phytotoxicity assay based on seed germination/ root elongation has been optimized and used to evaluate the toxic effects of some phenolic herbicides. The method has been improved by investigating the influence of experimental conditions. Lepidium sativum was chosen as the most suitable species, showing high germinability, good repeatability of root length measurements, and low sensitivity to seed pretreatment. DMSO was the most appropriate solvent carrier for less water-soluble compounds. Three dinitrophenols and three hydroxybenzonitriles were tested: dinoterb, DNOC, 2,4-dinitrophenol, chloroxynil, bromoxynil, and ioxynil. Toxicity was also determined using the Vibrio fischeri Microtox ${ }^{\circledR}$ test, and a highly significant correlation was found between EC50 values obtained by the two assays. Dinoterb was the most toxic compound. The toxicity of hydroxybenzonitriles followed the order: ioxynil $>$ bromoxynil $>$ chloroxynil; $L$. sativum exhibited a slightly higher sensitivity than $V$. fischeri to these compounds. A QSAR analysis highlighted the importance of hydrophobic, electronic, and hydrogen-bonding interactions, in accordance with a mechanism of toxic action based on protonophoric
\end{abstract}

Responsible editor: Philippe Garrigues

Emanuele Argese

argese@unive.it

1 Department of Molecular Sciences and Nanosystems, Ca' Foscari University of Venice, Via Torino 155, 30172 Venezia, Italy

2 Department of Biomedical Sciences, University of Padova, Viale G. Colombo 3, 35131 Padua, Italy

3 Department of Philosophy and Cultural Heritage, Ca' Foscari University of Venice, Dorsoduro 3484/D, 30123 Venezia, Italy

4 Department of Environmental Sciences, Informatics and Statistics, Ca' Foscari University of Venice, Via Torino 155 , 30172 Venezia, Italy uncoupling of oxidative phosphorylation. The results suggest that the seed germination/root elongation assay with L. sativum is a valid tool for the assessment of xenobiotic toxicity and can be recommended as part of a test battery.

Keywords Phytotoxicity $\cdot$ Seed germination $\cdot$ Root elongation $\cdot$ Phenolic herbicides $\cdot$ Microtox $\cdot$ QSAR

\section{Introduction}

The knowledge of the toxic effects of pollutants is a key requirement for environmental risk assessment. A fundamental instrument in this field is given by ecotoxicological tests, which use organisms belonging to different trophic levels and involve different endpoints, targets, and modes of action. These bioassays can be used either individually or, preferably, as components of a test battery; this is especially recommended when evaluating the toxic effects of unknown substances, mixtures of chemicals, and samples of complex composition, such as wastes, effluents, and contaminated environmental matrices.

The most widespread ecotoxicological tests use bacteria and aquatic organisms, such as algae, fishes, and invertebrates, particularly crustaceans; for these assays, it is possible to find extensive collections of data for a large number of chemicals. Conversely, ecotoxicity testing with terrestrial organisms is much less common, data are not easily available, and knowledge on target sites and mode of action is still far from complete.

Because of the essential role played by plants in ecosystems and of the widespread use and environmental occurrence of chemicals with herbicidal action, the inclusion of phytotoxicity assays in test batteries could greatly improve their effectiveness and significance (Wang 1991). The relevance of phytotoxicity 
testing is also substantiated by its application in environmental assessment and is recognized by the environmental legislation in many countries and by regulatory authorities, which have developed specific guidelines for test conduction (OECD 1984, 2006; US FDA 1987; USEPA 1996). However, both in the aquatic and the terrestrial environment, ecotoxicity tests with higher plants are not widely used, despite their crucial and recognized importance in environmental biomonitoring. Though phytotoxicity tests possess several advantages, their main limitation lies just in the scarcity of literature data, which may hamper a thorough comparative evaluation of methods, protocols, and results (Wang and Freemark 1995; Gong et al. 2001; Wang et al. 2001; Moore and Kröger 2010).

However, in the last years, the interest on phytotoxicity tests has been growing, especially those based on seed germination and/or root elongation of higher plants, as proved by the number of recent studies in which they were applied to environmental samples of varying origin and composition, such as soils, sediments, sludges, wastewater, compost (Beltrami et al. 1999; Gong et al. 2001; Barbero et al. 2001; Banks and Schultz 2005; Valerio et al. 2007; Devesa-Rey et al. 2008; Tiquia 2010; Rodriguez-Ruiz et al. 2014), and to various contaminants of concern, such as nanoparticles, metals, drugs, pesticides, and others (Lin and Xing 2007; Di Salvatore et al. 2008; Jin et al. 2009; Ma et al. 2010; Moore and Kröger 2010; Hillis et al. 2011; Manzo et al. 2011).

These assays are among the most advantageous for these purposes. They are simple and inexpensive, require minimal laboratory equipment, seeds can be stored for rather long periods with minimal costs, and tests can be activated quickly. Different methods and protocols are found in the literature, using different seed species, exposure time, and toxicity endpoint, with root elongation showing in general a higher sensitivity than seed germination. Zucconi et al. (1985) first proposed the use of a germination index, which combines both endpoints and allows thus to take into account the effects of toxicants both on the early phase of seed germination and on initial seedling growth; since then, many authors adopted this approach.

In this work, a seed germination/root elongation assay procedure has been optimized by comparing three seed species, chosen among the most used and recommended ones (Lepidium sativum, Lactuca sativa, and Cucumis sativus) and by evaluating the effects of experimental conditions, such as seed pre-treatment and the use of organic solvent carriers for less water soluble compounds. It is actually recognized that the results of phytotoxicity assays are often affected by a rather high variability, which could be reduced through a rigorous design and a strict control of testing parameters.

The assay was then applied to determine the toxicity of different phenolic herbicides and to investigate their mechanism of action; the names and the molecular structures of the tested compounds are reported in Table 1.
The dinitrophenols 2,4-DNP (2,4-dinitrophenol), DNOC (4,6-dinitro-o-cresol), and dinoterb (2-tert-butyl-4,6-dinitrophenol) are among the first organic chemicals patented for selective weed control and, thanks to their broad spectrum of activity, were widely used in the past as dye intermediates, wood preservatives, herbicides, insecticides, and sliming drugs (Kearney and Kaufman 1975; Gasiewicz 1991). They are typical contact herbicides, but their use in agriculture is now restricted or banned in many countries, mostly because of their persistence and of their high toxicity towards non-target organisms; however, their presence is still detected in the environment (Fobbe et al. 2006).

The benzonitriles ioxynil (3,5-diiodo,4hydroxybenzonitrile), bromoxynil (3,5-dibromo,4hydroxybenzonitrile), and chloroxynil (3,5-dichloro,4hydroxybenzonitrile) are also long-known compounds with herbicidal activity (Wain 1963; Carpenter and Heywood 1963); bromoxymil and ioxynil are currently used worldwide as selective post-emergence agents to control broadleaf weeds in cereal crops (Gasiewicz 1991; Fobbe et al. 2006). However, while plenty of studies on the ecotoxicological behavior of dinitrophenols can be found in the literature, information about benzonitriles is not so well documented, and few toxicity data are available.

With the purpose of a further validation of the seed germination/root elongation assay, toxicity was measured also by the Vibrio fischeri Microtox ${ }^{\circledR}$ test, a well-established bioassay based on bacterial bioluminescence inhibition; in addition, the acquired data were compared with those obtained in a previous study by a short-term in vitro assay based on mitochondrial respiratory functions (Argese et al. 2005) and with literature data for fish acute toxicity from standard tests.

Finally, quantitative structure-activity relationships (QSARs) were developed and discussed, with the aims of investigating the mechanisms of action of the examined compounds and highlighting the structural properties responsible for their toxic effects in the different testing systems.

\section{Materials and methods}

\section{Materials}

The examined herbicides were of Pestanal ${ }^{\circledR}$ grade from Riedel-de-Haën (Milan, Italy). Ethanol and dimethyl sulfoxide (DMSO) were of analytical grade from Sigma-Aldrich (Milan, Italy). Deionized water was prepared using a Milli$\mathrm{Q}^{\circledR}$ system (Millipore, Bedford, MA).

Seeds of L. sativum, L. sativa and C. sativus were supplied by F.lli Ingegnoli (Milan, Italy) in single, closed bags.

The microrganism $V$. fischeri was supplied as lyophilized cells by Azur Environmental (Carlsbad, CA, USA), together with all materials and reagents required for conducting the 
Table 1 Names and structural formulas of the examined compounds

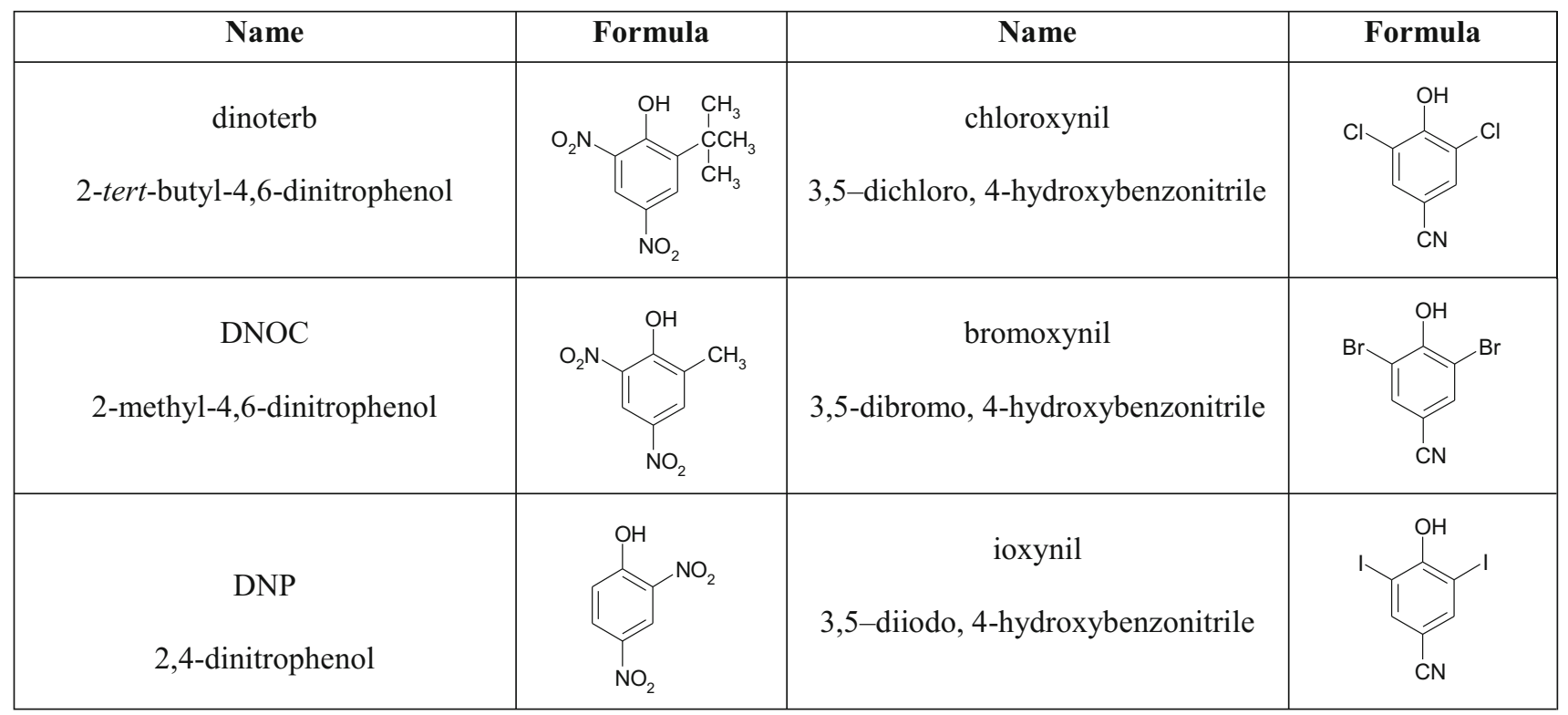

Microtox ${ }^{\circledR}$ assay, including reagent, reconstituent solution and diluent ( $2 \%$ sterile $\mathrm{NaCl}$ solution).

\section{Seed germination and root elongation assay}

The tests were conducted using glass petri dishes (100-mm diameter) and Whatmann $\mathrm{N}^{\circ} 1$ filter paper. Ten undamaged seeds of similar size were placed uniformly on the surface of the filter paper, at the bottom of each dish, which contained $5 \mathrm{ml}$ of test solution (or deionized water for the control). Dishes were then closed and incubated in the dark at 25 $\pm 0.5^{\circ} \mathrm{C}$. Four replicates were carried out for each concentration of test solution, as well as for the control. After 72 hours of incubation, the germinated seeds were counted, and the root length was measured on all seedlings. Seeds were considered germinated when the radicle was longer than $1 \mathrm{~mm}$.

The two endpoints were combined into a germination index (GI), calculated according to the following equation:

$G I=100 \cdot \frac{G s \cdot L s}{G c \cdot L c}$

where Gs and Ls are seed germination and root elongation ( $\mathrm{mm}$ ) values for the test solution, whereas Gc and Lc are the corresponding values for the control (Zucconi et al. 1985; Barbero et al. 2001). For each compound, toxicity was expressed as EC50 value, i.e., the concentration that reduces the germination index by $50 \%$ with respect to the control. EC50 values with their $95 \%$ confidence limits were calculated by probit analysis.

The effect of seed pretreatment with sodium hypochlorite $(\mathrm{NaClO})$ was evaluated using two solutions with different concentrations ( 0.5 and $4 \%$, respectively). Seeds were soaked for $20 \mathrm{~min}$ in the solutions and then carefully rinsed with deionized water; after this treatment, they were allowed to germinate using deionized water as growth medium, under the conditions described above. Germination and root elongation were then compared to those of non-pretreated seeds.

DNOC was dissolved in deionized water, whereas the concentrated stock solutions of the other compounds, which had a lower water solubility, were prepared using an organic solvent. Dimethyl sulfoxide (DMSO) and ethanol were tested, and DMSO was chosen as the most suitable solvent. Dilute test solutions were prepared using deionized water, and final concentrations of DMSO were always below $0.5 \%$.

Repeatability experiments using $\mathrm{Cr}(\mathrm{VI})$ and 2,4-dinitrophenol as reference toxicants were performed by carrying out five replicates over a 6-month period.

\section{Microtox ${ }^{\circledR}$ assay}

The tests were carried out according to standard protocols supplied by Azur environmental (Azur environmental 1998). DNOC was dissolved in the supplied $2 \% \mathrm{NaCl}$ aqueous solution, while the other compounds were dissolved in $2 \%$ $\mathrm{NaCl}$ with $0.4 \%(v / v)$ ethanol. This concentration is below the maximum allowable concentration (MAC) of $1 \%(v / v)$, reported to exhibit no significant effects (Salizzato et al. 1998).

Bacterial suspension light outputs were detected by a Microtox $^{\circledR}$ analyzer (model M500) after 5 and 15 min of exposure. The toxicity endpoint (EC50), which represents the concentration of the test compound that caused a $50 \%$ reduction in light output, was calculated using the instrument software. 


\section{Quantitative structure-activity relationships (QSAR)}

Toxicity values for the various assays were expressed as the logarithm of the inverse molar concentration. The hydrophobicity of the tested compounds is described by the octanol/ water partition coefficient $\left(\log \mathrm{K}_{\text {ow }}\right)$, whereas the acid dissociation constant $\left(\mathrm{p} K_{\mathrm{a}}\right)$, the dipole moment $(\mu)$, and the Hammet sigma $(\Sigma \sigma)$ are used as descriptors of the electronic effects. $\Sigma \sigma$ was calculated as the sum of Hammett $\sigma$ constants of the individual substituents present on the phenolic ring (values taken from Hansch et al. 1991); para substituent constants were used also for ortho substituents. The molecular volume $\left(\mathrm{V}_{\mathrm{mc}}\right)$ is used to evaluate the influence of the steric properties of the compounds. $\mathrm{E}_{\mathrm{HOMO}}$ (the energy of the highest occupied molecular orbital) is used as a descriptor for hydrogen bonding acceptor capacity, which increases with increasing $\mathrm{E}_{\mathrm{HOMO}}$. The hydrogen-bonding donor capacity is described by $\mathrm{E}_{\text {LUMO }}$ (the energy of the lowest unoccupied molecular orbital) and increases with decreasing $\mathrm{E}_{\mathrm{LUMO}}$ (Urrestarazu Ramos et al. 1998).

$\mathrm{E}_{\text {Hомо }}$ and $\mathrm{E}_{\mathrm{LUMO}}$ values were calculated using the Spartan program package (version 4.0. Wave Function, Irvine, CA, USA) running on an Indy workstation. Geometry optimization was performed using the semiempirical PM3 procedure, and energies and partial charges (Mulliken) were recalculated at the ab initio 6-31 G level. $\mathrm{V}_{\mathrm{mc}}$, and $\mu$ values were calculated using the HyperChem program (version 6.01, Hypercube, Gainesville, FL, USA).

Linear regression analysis was used to produce quantitative structure-activity relationships, by using the Statistica software (version 6.0, StatSoft Inc., Tulsa, OK, USA). The quality of the models was estimated from the coefficient of determination $\left(R^{2}\right)$, the standard error of estimate (s), the ANOVA ratio for regression (F), and the $p$ value $(p)$.

\section{Results and discussion}

\section{Optimization and evaluation of the phytotoxicity testing protocol}

The effect of surface seed sterilization with sodium hypochlorite and the response variability of the three seed species are illustrated in Fig. 1. As can be seen, seed pretreatment increased the germination rate only in $L$. sativa, while root growth was negatively affected in all the tested species. This suggests that seed sterilization, often carried out routinely, should be carefully evaluated and avoided if not favorable.

Based on the relative response of the three plants, L. sativum was the most suitable test species, showing a maximum germination rate, an optimal root growth, and a lower variability. In addition, the repeatability of germination rate and root length measurements, assessed in a control test (five repetitions, with four replicated dishes containing ten seeds each, no seed pretreatment), was very satisfactory: germination rate was always $100 \%$, and the average root length was $43.6 \pm 2.3 \mathrm{~mm}$, with a low variability within each repetition (coefficient of variation between 4 and $12 \%$ ).

The effect of organic solvent carriers was also evaluated, since information about maximum allowed concentrations in phytotoxicity testing is scarce. The EPA and OECD guidelines do not suggest any preferred solvent carrier, but checking for their effect is recommended (OECD 1984; USEPA 1996). Two solvents commonly used as delivery vehicles in toxicity assays, ethanol and dimethyl sulfoxide (DMSO), were therefore tested at four final concentrations: $0.01,0.1,1$, and $2 \%$ $v / v$. Ethanol caused a reduction of the germination index even at the lowest concentration, yielding an EC50 value of $0.45 \%$ $v / v$. Conversely, DMSO showed a slight negative effect only at $2 \% v / v(\mathrm{GI}=82 \%$ of the control). These results are comparable to the few available data on plants. Ethanol at a $117-\mathrm{mM}$ concentration (corresponding to about $0.68 \% \mathrm{v} / \mathrm{v}$ ), was shown to reduce the germination of $L$. sativa seeds by $50 \%$ of the control (Reynolds 1977), while root length growth in the Allium test was found to be $33.8 \%$ of the control at $2 \% v / v$ ethanol (Fiskesjö 1985). On the other hand, root growth of germinated seedlings of L. sativa, exposed to $1 \% v / v$ DMSO, was not significantly affected (Sawhney and Srivastava 1977). Unfortunately, recent phytotoxicity studies mostly lack an evaluation on the effects of organic solvent carriers, which are simply included in the controls. Our results are also in accordance with both acute and chronic toxicity to aquatic organisms (Hutchinson et al. 2006). Specifically, in a 96-h growth bioassay with green algae, DMSO in the range $0.05-1 \% v / v$ showed no significant effects, while ethanol at the same concentrations caused a significant growth inhibition (El Jay 1996); additional evidence of the lower toxicity of DMSO is reported for nine species of microalgae (Okumura et al. 2001). DMSO was therefore selected for phytotoxicity testing and was always employed at a final concentration below $0.5 \%(v / v)$.

The repeatability and stability of the L. sativum assay was then assessed over a 6-month period, using 2,4-DNP — one of the phenolic compounds examined in this study — and $\mathrm{Cr}(\mathrm{VI})$, recommended as a reference toxicant (Wang 1987a; Beltrami et al. 1999). As shown by the results reported in Table 2, the variability of EC50 measurements undoubtedly satisfies acceptability criteria in ecotoxicity testing.

A comparison with literature data (Table 3 ) shows that the average EC50 value for $\mathrm{Cr}(\mathrm{VI})$ is of the same order of magnitude of those found in similar conditions for $L$. sativum and for other species, such as L. sativa and Panicum miliaceum. Conversely, C. sativus and Sinapis alba seem to exhibit a lower sensitivity. No data were found on 2,4-DNP phytotoxicity to L. sativum; anyhow, the EC50 value determined in this study is comparable to most data for commonly used species, 
Fig 1 Effect of seed pretreatment with sodium hypochlorite on germination and root elongation in Lepidium sativum, Cucumis sativus, and Lactuca sativa. Results are from four replicated dishes, each containing ten seeds. Deionized water was used as growth medium. Error bars represent the coefficients of variation $(\mathrm{CV})$

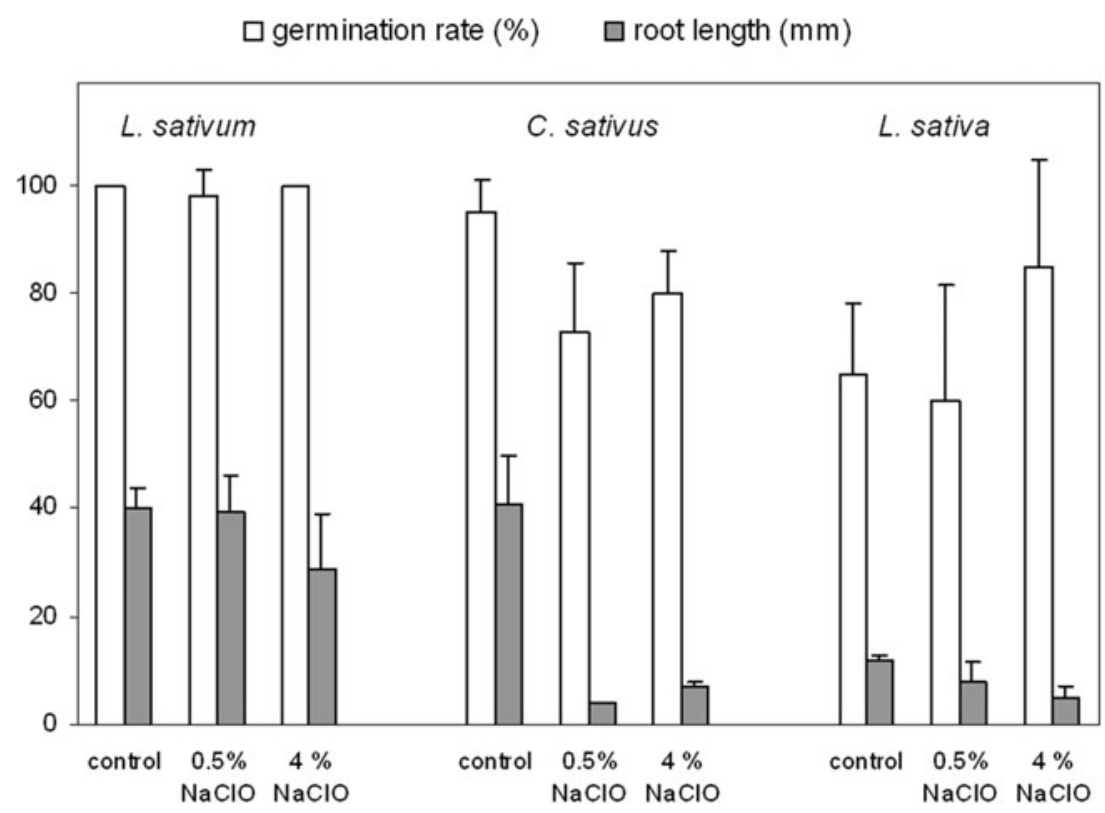

including C. sativus, especially for root elongation inhibition, which is in general the most sensitive endpoint. Only Glycine $\max$, in a seed germination/root elongation assay, showed a significantly lower sensitivity.

\section{Phenolic herbicide toxicity}

After the optimization of experimental conditions and the evaluation of test performance, the seed germination/root elongation assay with $L$. sativum was used to determine the phytotoxic effects of the six phenolic herbicides shown in Table 1. Table 4 reports the resultant EC50 values, together with those obtained with the Microtox ${ }^{\circledR}$ assay.

Dinoterb was found to be the most toxic compound with both assays, which yielded very similar EC50 values. In general, the L. sativum assay exhibited a slightly higher sensitivity, especially for hydroxybenzonitriles; the phytotoxicity of these structurally related chemicals varied with the type of halogen substituent, decreasing in the order $\mathrm{I}>\mathrm{Br}>\mathrm{Cl}$. The

Table 2 Repeatability of the Lepidium sativum assay, with Cr (VI) and 2,4-DNP as reference toxicants

\begin{tabular}{lll}
\hline Test & $\begin{array}{l}\text { Cr (VI) } \\
\text { EC50 }(95 \% \text { C.I. }) m g / L\end{array}$ & $\begin{array}{l}\text { 2,4-DNP } \\
\text { EC50 (95 \% C.I.) } m g / L\end{array}$ \\
\hline 1 & $9.7(7.1-12.4)$ & $4.15(3.92-4.36)$ \\
2 & $11.5(9.8-13.5)$ & $3.71(3.02-4.42)$ \\
3 & $9.5(7.0-12.9)$ & $3.77(3.12-4.43)$ \\
4 & $8.2(5.9-10.5)$ & $4.55(3.85-5.29)$ \\
5 & $10.2(8.1-12.3)$ & $4.99(4.31-5.73)$ \\
Mean \pm SD & $9.8 \pm 1.2$ & $4.23 \pm 0.54$ \\
CV & $12 \%$ & $13 \%$ \\
\hline
\end{tabular}

phytotoxicity of dinitrophenols followed the order dinoterb $>$ DNOC $>2$,4-DNP, showing that toxic effects are increased by the presence of an alkyl ortho substituent on the benzene ring; moreover, the larger the alkyl group, the higher the toxicity. The Microtox ${ }^{\circledR}$ assay showed the same trend.

The results of the two assays were compared quantitatively by means of linear regression analysis; a further comparison was made using literature data on fish acute toxicity (96-h LC50 for the fathead minnow Pimephales promelas, retrieved from the US EPA ECOTOX database, http://www.epa.gov/ ecotox) and EC50 values determined by a mitochondrial in vitro assay (SMP assay) in a previous study (Argese et al. 2005). Unfortunately, other consistent datasets for the whole series of compounds were not found, both for terrestrial and aquatic organisms.

Given the high degree of correlation between Microtox ${ }^{\circledR}$ EC50 values at 5-min and $15-\min \left(R^{2}=0.986, R_{\text {adj }}^{2}=0.983\right.$, $s=0.076, F=289, p<0.00007$ ), with slope and intercept of the regression line close to 1 and 0 , respectively, the following analyses included only 15-min EC50 values. Figure $2 \mathrm{a}-\mathrm{d}$ illustrates the results of regression analysis. A good correlation exists between L. sativum and Microtox ${ }^{\circledR}$ EC50 values $\left(R^{2}=0.918, R_{\text {adj }}^{2}=0.898, s=0.189, F=44.84, p<0.003\right)$; only DNOC is slightly displaced from the regression line (Fig. 2a). On the other hand, the correlation between L. sativum EC50s and fish LC50s is weaker, but still significant $\left(R^{2}=0.668, R_{\text {adj }}^{2}=0.584, s=0.718, F=8.03, p<0.05\right)$. As can be seen in Fig. 2b, fish LC50 values span over a wider range (more than three orders of magnitude), with $L$. sativum showing a higher sensitivity to hydroxybenzonitriles and 2,4DNP than P. promelas. The Microtox ${ }^{\circledR}$ assay (Fig. 2d) displayed a more robust correlation with fish acute toxicity $\left(R^{2}=0.872, R_{\text {adj }}^{2}=0.840, s=0.445, F=27.2, p<0.006\right)$, with 
Table 3 Literature data on phytotoxicity of CrVI and 2,4-DNP, determined by seed germination and root elongation assays

\begin{tabular}{|c|c|c|c|c|}
\hline Toxicant & Test species & Concentration (95 \% C.I.) (mg/L) & Endpoint & Reference \\
\hline \multirow[t]{7}{*}{ CrVI } & $\begin{array}{l}\text { Cucumis sativus } \\
\text { Lactuca sativa }\end{array}$ & $\begin{array}{l}43.6(38.7-50.0) \\
7.5(4.0-12.8)\end{array}$ & \multirow[t]{2}{*}{ EC50 seed germination/root elongation $72 \mathrm{~h}$} & \multirow[t]{2}{*}{ Beltrami et al. (1999) } \\
\hline & Lepidium sativum & $4.4(3.1-5.8)$ & & \\
\hline & $\begin{array}{l}\text { Cucumis sativus } \\
\text { Lactuca sativa }\end{array}$ & $\begin{array}{l}44(36-60) \\
3.7(1.9-5.2)\end{array}$ & \multirow[t]{2}{*}{ IC50 root elongation $120 \mathrm{~h}$} & \multirow[t]{2}{*}{ Wang (1987b) } \\
\hline & Panicum miliaceum & $17(7.8-36)$ & & \\
\hline & Lepidium sativum & $1.8(1.5-1.9)$ & EC50 root elongation $48 \mathrm{~h}$ & $\begin{array}{l}\text { Montvydienė and } \\
\text { Marčiulionienè (2004) }\end{array}$ \\
\hline & Sinapis alba & $100(89.76-103.85)$ & EC50 seed germination $72 \mathrm{~h}$ & Fargašová (1994) \\
\hline & Sinapis alba & $45.71(38.65-50.46)$ & EC50 root elongation $72 \mathrm{~h}$ & Fargašová (1994) \\
\hline \multirow[t]{6}{*}{ 2,4-DNP } & Glycine $\max$ & 143 (n.r.) ${ }^{\mathrm{a}}$ & IC50 seed germination/root elongation $96 \mathrm{~h}$ & Gramatica et al. (2002) \\
\hline & Cucumis sativus & 10.7 (n.r.) & $\mathrm{RC} 50$ root elongation $48 \mathrm{~h}$ & Wang et al. (2000) \\
\hline & Cucumis sativus & 100.6 (n.r.) & GC50 seed germination $48 \mathrm{~h}$ & Wang et al. (2002a) \\
\hline & $\begin{array}{l}\text { Brassica spp. } \\
\text { Cucumis spp. }\end{array}$ & $\begin{array}{l}17 \text { (n.r.) }{ }^{\mathrm{b}} \\
11 \text { (n.r.) }\end{array}$ & \multirow[t]{3}{*}{ EC50 root elongation $120 \mathrm{~h}$} & \multirow[t]{3}{*}{ Siddiqui et al. (2011) } \\
\hline & Panicum spp. & 3.7 (n.r.) ${ }^{b}$ & & \\
\hline & Phaseolus spp. & 15 (n.r.) ${ }^{b}$ & & \\
\hline
\end{tabular}

n.r. not reported

${ }^{\text {a }}$ calculated from $\log (1 / \mathrm{IC} 50)=0.11$ (concentration values in $\mathrm{mmol} / \mathrm{L}$ )

${ }^{\mathrm{b}}$ calculated from EC50 values in $\mathrm{mol} / \mathrm{L}$

lower differences in sensitivity between the two assays, except for dinoterb. No significant correlations were found between the SMP assay and both L. sativum (Fig. 2c) and V. fisheri (results not shown), but the SMP assay exhibited a higher sensitivity for all compounds.

These results are consistent with the current knowledge about the examined compounds. While dinitrophenols are well known as potent protonophoric uncouplers of oxidative and photosynthetic phosphorylation, the mode of action of the hydroxybenzonitrile halogeno-derivates appears more complex; these compounds are also reported to be uncouplers, but they exert most of their herbicidal action through the inhibition of electron transport in photosystem II (Fedtke and Duke 2005; Fobbe et al. 2006; Casida 2009). However, photosynthetic pathways are not involved in seed germination and early seedling growth, which are heterotrophic processes that rely on respiratory metabolism. Thus, both dinitrophenols and hydroxybenzonitriles are supposed to exert their toxic effects by uncoupling ATP production from electron transport in seed mitochondria. This in turn can affect a number of ATPrequiring processes that are fundamental for germination and radicle growth, resulting in a reduction of GI in the phytotoxicity assay used in this study.

An uncoupling action can account also for the inhibition of bioluminescence in the Microtox ${ }^{\circledR}$ assay, since light production in $V$. fischeri requires ATP and is tied directly to cell respiration. This can explain the high degree of correlation between the two assays.

On the other hand, the lack of correlation with the SMP assay is most likely due to the different structural properties of

Table 4 EC50 values obtained by the Lepidium sativum and the Microtox ${ }^{\circledR}$ assays ( $95 \%$ confidence intervals are given in parentheses)

\begin{tabular}{|c|c|c|c|c|c|c|}
\hline & \multicolumn{2}{|l|}{ L. sativum EC50 } & \multicolumn{2}{|c|}{ Microtox $^{\circledR} 5$-min EC50 } & \multicolumn{2}{|c|}{ Microtox $^{\circledR} 15-\min$ EC50 } \\
\hline & $\mathrm{mg} / \mathrm{L}$ & $\mu \mathrm{M}$ & $\mathrm{mg} / \mathrm{L}$ & $\mu \mathrm{M}$ & $\mathrm{mg} / \mathrm{L}$ & $\mu \mathrm{M}$ \\
\hline 2,4-DNP & $4.15(3.92-4.36)$ & 22.5 & $14.3(13.1-15.6)$ & 77.7 & $13.8(12.3-15.6)$ & 75.0 \\
\hline 2-DNOC & $3.88(3.59-4.18)$ & 19.6 & $4.17(3.94-4.42)$ & 21.0 & $5.67(5.16-6.22)$ & 28.6 \\
\hline Dinoterb & $0.384(0.283-0.485)$ & 1.60 & $0.407(0.365-0.453)$ & 1.69 & $0.371(0.355-0.440)$ & 1.54 \\
\hline chloroxynil & $2.87(2.28-3.05)$ & 15.3 & $8.58(7.51-10.9)$ & 45.6 & $7.85(5.72-10.6)$ & 41.8 \\
\hline bromoxynil & $2.41(2.24-3.01)$ & 8.70 & $7.69(6.10-8.53)$ & 27.8 & $7.30(6.69-8.51)$ & 26.4 \\
\hline ioxynil & $1.85(1.56-2.36)$ & 4.99 & $4.26(4.16-4.36)$ & 11.5 & $4.82(4.41-5.32)$ & 13.0 \\
\hline
\end{tabular}



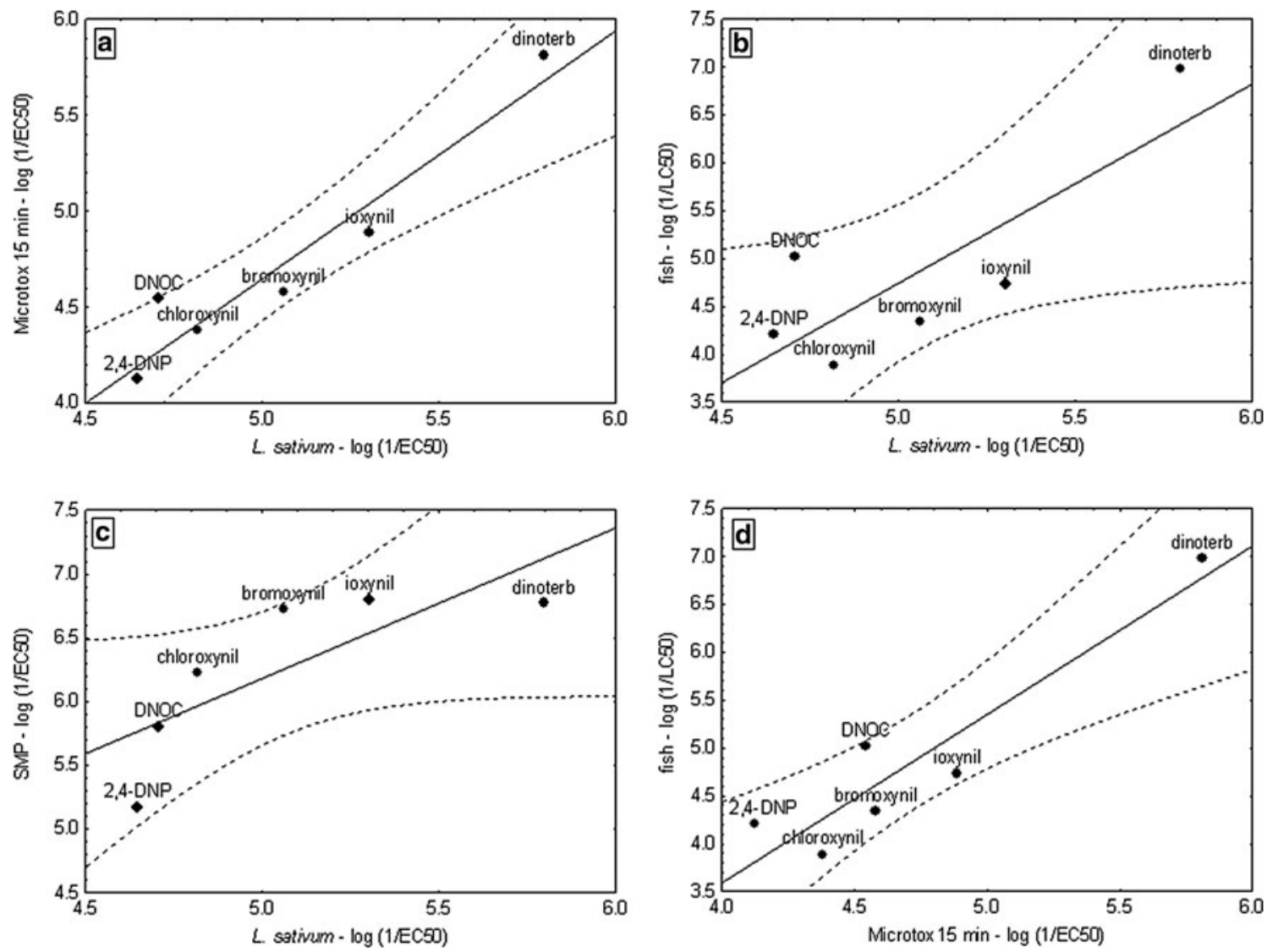

Fig. 2 Results of linear regression analysis between toxicity data. The dotted lines represent $95 \%$ confidence limits

the three testing systems. SMPs are artificial structures, obtained by disruption of mammalian mitochondria. They are inside-out vesicles of the inner mitochondrial membrane, where the proteins involved in electron transport and ATP synthesis are directly exposed to toxicants in the assay medium (Argese et al. 2005); this can explain the higher sensitivity shown by the SMP assay. In seeds and bacteria, conversely, toxic molecules have to cross cell wall and membranes before they can reach their targets (the inner mitochondrial membrane in seeds and the plasma membrane in $V$. fischeri), and more complex interactions are necessarily involved in xenobiotic passage across these barriers.

The weak correlation with the fish acute toxicity assay can be ascribed as well to the number of processes that may occur during the 96-h exposure in vivo, such as toxicant absorption, biotransformation, and excretion, which could follow different pathways or have different rates for the two subgroups of phenolic herbicides; this can cause the apparent separation observed in the graphs of Fig. 2b and d, and explain the lower sensitivity of fish to hydroxybenzonitriles, with respect to dinitrophenols.

\section{Quantitative structure-activity relationships}

Phytotoxicity assays have proved suitable to investigate the mechanism of toxic action of various organic pollutants by means of quantitative structure-activity relationships, but the number of related studies is very limited compared to those on aquatic toxicity (Hulzebos et al. 1991; Feng et al. 1996; Wang et al. 2000, 2002a, 2002b, 2002c; Gramatica et al. 2002).

A QSAR analysis was performed in order to provide information about the relationships between toxicity and physicochemical properties of the studied phenolic compounds and to highlight the biochemical processes involved.

The molecular descriptors used to establish QSARs, together with toxicity data for the examined compounds are reported in Table 5.

In order to distinguish and clearly estimate the contribution to toxicity of the different types of interactions, the intercorrelations among the various molecular descriptors were calculated. As shown in Table 6, a high degree of correlation exists between $\Sigma \sigma$ and $\mathrm{E}_{\mathrm{HOMO}}$ and between $\mu$ and $\mathrm{E}_{\mathrm{LUMO}}$; this should be necessarily taken into account in the discussion of multiple regression analysis results.

Simple regression analysis between EC50 values and QSAR parameters showed that no significant relationship occurs for any of the tests and of the molecular descriptors considered in the study, except for the SMP assay, for which a significant relationship exists between EC50 values and log $\mathrm{K}_{\mathrm{ow}}\left(R^{2}=0.952\right)$, as previously reported (Argese et al. 2005). Thus, when taken separately, none of the parameters is able to 
Table 5 Toxicity data and molecular descriptors used for QSAR analysis

\begin{tabular}{|c|c|c|c|c|c|c|c|c|c|c|c|}
\hline & $\begin{array}{l}\text { L. sativum } \\
\log (1 / \text { EC50) }\end{array}$ & $\begin{array}{l}\text { Microtox }^{\mathbb{R}} \\
15-\min \\
\log (1 / \text { EC } 50)\end{array}$ & $\begin{array}{l}\text { SMP } \\
\log (1 / \mathrm{EC} 50)\end{array}$ & $\begin{array}{l}\text { Fish } \\
96-\mathrm{h} \\
\log (1 / \mathrm{LC} 50)\end{array}$ & $\log K_{\text {ow }}$ & $\begin{array}{l}E_{\mathrm{HOMO}} \\
\text { (hartree) }\end{array}$ & $\begin{array}{l}E_{\text {LUMO }} \\
\text { (hartree) }\end{array}$ & $\begin{array}{l}\mu \\
\text { (debye) }\end{array}$ & $\mathrm{p} K_{\mathrm{a}}$ & $\Sigma \sigma$ & $\begin{array}{l}\mathrm{Vmc} \\
\left(\AA^{3}\right)\end{array}$ \\
\hline 2,4-DNP & 4.65 & 4.13 & $5.17^{\mathrm{b}}$ & 4.20 & $1.67^{\mathrm{a}}$ & -0.39194 & 0.03241 & 6.6345 & $3.94^{\mathrm{a}}$ & 1.56 & 157 \\
\hline 2-DNOC & 4.71 & 4.54 & $5.80^{\mathrm{b}}$ & 5.02 & $2.12^{\mathrm{a}}$ & -0.38250 & 0.03548 & 7.3110 & $4.31^{\mathrm{a}}$ & 1.39 & 168 \\
\hline dinoterb & 5.80 & 5.81 & $6.77^{\mathrm{b}}$ & 6.98 & $3.54^{\mathrm{a}}$ & -0.37732 & 0.02802 & 8.2138 & $4.80^{\mathrm{a}}$ & 1.36 & 213 \\
\hline chloroxynil & 4.82 & 4.38 & $6.23^{\mathrm{b}}$ & 3.89 & $2.90^{\mathrm{b}}$ & -0.35125 & 0.07396 & 3.1397 & $4.90^{\mathrm{c}}$ & 1.12 & 137 \\
\hline bromoxynil & 5.06 & 4.58 & $6.72^{\mathrm{b}}$ & 4.34 & $3.39^{\mathrm{b}}$ & -0.34566 & 0.07485 & 3.5504 & $4.30^{\mathrm{c}}$ & 1.12 & 186 \\
\hline ioxynil & 5.30 & 4.89 & $6.80^{\mathrm{b}}$ & 4.74 & $3.94^{\mathrm{b}}$ & -0.32896 & 0.07445 & 3.8446 & $4.50^{\mathrm{c}}$ & 1.02 & 216 \\
\hline
\end{tabular}

${ }^{a}$ Values taken from Escher and Schwarzenbach (1996)

${ }^{\mathrm{b}}$ Values taken from Argese et al. (2005)

${ }^{\mathrm{c}}$ Values taken from Nolte et al. (1995)

describe the toxicological behavior of the tested herbicides, suggesting that a sum of interactions between molecules and their target sites may be responsible for their toxic action.

Very different results were obtained using a two-parameter approach. Table 7 summarizes the results obtained by multiple regression analysis. For L. sativum, Microtox ${ }^{\circledR}$ and fish assays, significant correlations have been obtained whenever the hydrophobic descriptor log Kow was used as first independent variable, and $\mathrm{E}_{\mathrm{LUMO}}, \mathrm{E}_{\mathrm{HOMO}}$, the dipole moment or the Hammet $\sigma$ as a second independent variable. In contrast, for the SMP assay, no one of the additional descriptors yielded significant correlations (Argese et al. 2005). For the fish assay, other significant QSAR equations, not including $\log \mathrm{K}_{\mathrm{ow}}$, can be observed in Table 7, but they show a lower significance level and contain independent variables with a certain degree of intercorrelation (see Table 6).

A key consideration to interpret these results as a common basis to explain the mechanism of toxic action is the higher statistical value of the relationships that include $\log \mathrm{K}_{\mathrm{ow}}$. This parameter is a basic QSAR descriptor, used to characterize the hydrophobicity of chemicals and to model their ability to penetrate through biomembranes; thus, good correlations with log

Table 6 Correlation matrix showing correlation coefficients among the different molecular descriptors $(n=6)$

\begin{tabular}{lrllllll}
\hline & $\log K_{\mathrm{ow}}$ & $E_{\mathrm{HOMO}}$ & $E_{\mathrm{LUMO}}$ & $M$ & $\mathrm{p} K_{\mathrm{a}}$ & $\Sigma \sigma$ & $V_{\mathrm{mc}}$ \\
\hline $\log K_{\mathrm{ow}}$ & 1.00 & & & & & & \\
$E_{\mathrm{HOMO}}$ & 0.79 & 1.00 & & & & & \\
$E_{\mathrm{LUMO}}$ & 0.54 & $0.92^{*}$ & 1.00 & & & & \\
$\mu$ & -0.38 & $-0.83^{*}$ & $-0.97^{*}$ & 1.00 & & & \\
$\mathrm{p} K_{\mathrm{a}}$ & 0.60 & 0.38 & 0.27 & -0.18 & 1.00 & & \\
$\Sigma \sigma$ & -0.79 & $-0.97^{*}$ & $-0.91^{*}$ & $0.81^{*}$ & -0.51 & 1.00 & \\
$V_{\mathrm{mc}}$ & 0.71 & 0.32 & -0.03 & 0.20 & 0.11 & -0.26 & 1.00 \\
\hline
\end{tabular}

Correlations marked with an asterisk are significant at $p<0.05$
$\mathrm{K}_{\mathrm{ow}}$ confirm that the toxic action involves membrane processes.

The QSAR analysis suggests that hydrophobicity plays a major role in the interaction between the examined substances and their sites of action in all the assays. Besides hydrophobicity, the molecular interactions best describing the toxicity values are the electronic and hydrogen bonding ones, leading to models without outliers.

These results are consistent with a mechanism of toxicity based on protonophoric uncoupling of oxidative phosphorylation, that is the ability of molecules to translocate protons across the inner mitochondrial membrane (in seeds and fish) and the plasma membrane (in bacteria), thus dissipating the transmembrane proton gradient necessary for ATP synthesis (Argese et al. 1999).

All the examined herbicides are lipophilic weak acids that partition easily into the lipid bilayer of membranes; the shuttle mechanism of protonophoric uncoupling requires that both the neutral protonated and the dissociated form be able to diffuse across the membrane, with the phenoxide ion playing a major role at the $\mathrm{pH}$ values used in the assays considered in this study, which resemble ambient $\mathrm{pH}$ values (Escher and Schwarzenbach 1996). The mobility of the phenoxide ion in the lipid bilayer is strongly influenced by charge delocalization in the molecule, which can be favored by the presence of electron-withdrawing substituents on the benzene ring; dinitrophenols contain two nitro groups in the ortho- and paraposition to the phenoxide group, while hydroxybenzonitriles exhibit one para-nitrile group and two halogen substituents in the ortho-position. As can be seen in Fig. 3, these electronwithdrawing substituents contribute to charge delocalization, thus increasing phenoxide mobility in the lipid bilayer. Though presenting an electron-donor group in the ortho-position, dinoterb was found to be the most potent uncoupler among the examined phenolic compounds. This is supposed to be to an effect of the bulky alkyl substituent, which not only increases the hydrophobicity of the compound, but also causes 
Table 7 Results of linear regression analysis between toxicity data and the molecular descriptors used for the QSAR analysis $(n=6)$

\begin{tabular}{|c|c|c|c|c|c|c|}
\hline Test & Regression equativo & $R^{2}$ & $R_{a d j}^{2}$ & $F$ & $s$ & $p$ \\
\hline \multirow[t]{4}{*}{ L. sativum } & $\log (1 / \mathrm{EC} 50)=0.78 \log \mathrm{K}_{\mathrm{ow}}-17.7 \mathrm{E}_{\mathrm{HOMO}}-3.67$ & 0.986 & 0.976 & 104.07 & 0.067 & 0.002 \\
\hline & $\log (1 / \mathrm{EC} 50)=0.58 \log \mathrm{K}_{\mathrm{ow}}-13.3 \mathrm{E}_{\mathrm{LUMO}}+4.05$ & 0.974 & 0.957 & 57.28 & 0.090 & 0.004 \\
\hline & $\log (1 / \mathrm{EC} 50)=0.79 \log \mathrm{K}_{\mathrm{ow}}+2.12 \Sigma \sigma+0.06$ & 0.982 & 0.970 & 82.18 & 0.076 & 0.002 \\
\hline & $\log (1 / \mathrm{EC} 50)=0.51 \log \mathrm{K}_{\mathrm{ow}}+0.12 \mu+2.88$ & 0.946 & 0.911 & 26.48 & 0.131 & 0.01 \\
\hline \multirow[t]{4}{*}{ Microtox $^{\circledR}$} & $\log (1 / \mathrm{EC} 50)=1.08 \log \mathrm{K}_{\mathrm{ow}}-29.4 \mathrm{E}_{\mathrm{HOMO}}-9.13$ & 0.973 & 0.956 & 55.18 & 0.124 & 0.004 \\
\hline & $\log (1 / \mathrm{EC} 50)=0.76 \log \mathrm{K}_{\mathrm{ow}}-22.4 \mathrm{E}_{\mathrm{LUMO}}+3.69$ & 0.969 & 0.949 & 47.05 & 0.134 & 0.005 \\
\hline & $\log (1 / \mathrm{EC} 50)=1.04 \log \mathrm{K}_{\mathrm{ow}}+3.24 \Sigma \sigma-2.43$ & 0.883 & 0.806 & 11.37 & 0.260 & 0.04 \\
\hline & $\log (1 / \mathrm{EC} 50)=0.64 \log \mathrm{K}_{\mathrm{ow}}+0.21 \mu+1.66$ & 0.962 & 0.937 & 37.93 & 0.149 & 0.007 \\
\hline \multirow[t]{5}{*}{ Fish } & $\log (1 / \mathrm{LC} 50)=1.94 \log \mathrm{K}_{\mathrm{ow}}-67.8 \mathrm{E}_{\mathrm{HOMO}}-25.4$ & 0.948 & 0.913 & 27.39 & 0.327 & 0.01 \\
\hline & $\log (1 / \mathrm{LC} 50)=1.20 \log \mathrm{K}_{\mathrm{ow}}-52.5 \mathrm{E}_{\mathrm{LUMO}}+4.15$ & 0.971 & 0.952 & 50.75 & 0.243 & 0.005 \\
\hline & $\log (1 / \mathrm{LC} 50)=0.93 \log \mathrm{K}_{\mathrm{ow}}+0.51 \mu-0.64$ & 0.977 & 0.961 & 62.81 & 0.219 & 0.004 \\
\hline & $\log (1 / \mathrm{LC} 50)=-1.08 \mathrm{E}_{\mathrm{LUMO}}-9.91 \Sigma \sigma+23.1$ & 0.901 & 0.835 & 13.63 & 0.452 & 0.03 \\
\hline & $\log (1 / \mathrm{LC} 50)=0.80 \mu-5.66 \Sigma \sigma+7.63$ & 0.891 & 0.819 & 12.29 & 0.473 & 0.04 \\
\hline SMP & $\log (1 / \mathrm{EC} 50)=0.73 \log \mathrm{K}_{\mathrm{ow}}+4.11$ & 0.952 & 0.940 & 78.96 & 0.161 & 0.0009 \\
\hline
\end{tabular}

a shielding of the negative charge of the phenoxide ion (Escher and Schwarzenbach 1996).

\section{Conclusions}

The results of this study suggest that the toxic action of the examined compounds, though displaying different potency, involves metabolic processes that share common features also in organisms characterized by great physiological and morphological differences, such as seeds, bacteria, and fishes. This proves the effectiveness of phytotoxicity assays based on seed germination/root elongation for the detection of the toxic effect of xenobiotics both on target and non-target organisms and confirms their environmental relevance, making them suitable for the ecotoxicological assessment of environmental samples.

The rather simple and inexpensive testing protocol of the seed germination/root elongation assay employed in this study, together with the use of a species characterized by high sensitivity, such as $L$. sativum, may represent a further advantage for its application as a screening test as well as for inclusion in test batteries; however, the results showed that the optimization of experimental conditions is a basic requirement to improve the reliability and repeatability of toxicity measurements.
Fig. 3 Main resonance structures of 2,4-dinotrophenol (a) and of dihalogenated hydroxybenzonitriles (b)<smiles>O=[N+]([O-])c1ccc(O)c([N+](=O)[O-])c1</smiles><smiles>COCC1C=C([N+](=O)[O-])C=CC1=O</smiles><smiles>O=C1C=CC(=[N+]([O-])[O-])C=C1[N+](=O)[O-]</smiles><smiles>[X]C1=CC(=C=[N-])C=C([X])C1=O</smiles> 
The comparison with the response of other assays and the results of the QSAR analysis support the hypothesis that both in phenolic and in hydroxybenzonitrile herbicides, a mechanism of toxic action based on protonophoric uncoupling of oxidative phosphorylation is operative and, ultimately, highlight the importance of using batteries including both shortterm in vitro tests and standard in vivo assays for a thorough assessment of xenobiotic toxicity.

\section{References}

Argese E, Bettiol C, Giurin G, Miana P (1999) Quantitative structureactivity relationships for the toxicity of chlorophenols to mammalian submitochondrial particles. Chemosphere 38:2281-2292

Argese E, Bettiol C, Marchetto D, De Vettori S, Zambon A, Miana P, Ghetti PF (2005) Study on the toxicity of phenolic and phenoxy herbicides using the submitochondrial particle assay. Toxicol In Vitro 19:1035-1043

Azur environmental (1998). Microtox ${ }^{\circledR}$ manual.

Banks MK, Schultz KE (2005) Comparison of plants for germination toxicity tests in petroleum-contaminated soils. Water Air Soil Pollut 167:211-219

Barbero P, Beltrami M, Baudo R, Rossi D (2001) Assessment of Lake Orta sediments phytotoxicity after the liming treatment. J Limnol 60:269-276

Beltrami M, Rossi D, Baudo R (1999) Phytotoxicity assessment of Lake Orta sediments. Aquat Ecosys Health Manage 2:391-401

Carpenter K, Heywood BJ (1963) Herbicidal action of 3:5-dihalogeno-4hydroxybenzonitriles. Nature 200:28-29

Casida JE (2009) Pest toxicology: the primary mechanisms of pesticide action. Chem Res Toxicol 22:609-619

Devesa-Rey R, Moldes AB, Dìa-Fierros F, Barral MT (2008) Toxicity of Anllòns river sediment extracts using Microtox ${ }^{\circledR}$ and the Zucconi phytotoxicity test. Bull Environ Contam Toxicol 80:225-230

Di Salvatore M, Carafa AM, Carratù G (2008) Assessment of heavy metals phytotoxicity using seed germination and root elongation tests: a comparison of two growth substrates. Chemosphere 73: $1461-1464$

El Jay A (1996) Toxic effects of organic solvents on the growth of Chlorella vulgaris and Selenastrum capricornutum. Bull Environ Contam Toxicol 57:191-198

Escher BI, Schwarzenbach RP (1996) Partitioning of substituted phenols in liposome-water, biomembrane-water, and octanol-water sistem. Environ Sci Technol 30:260-270

Fargašová A (1994) Effect of $\mathrm{Pb}, \mathrm{Cd}, \mathrm{Hg}, \mathrm{As}$, and $\mathrm{Cr}$ on germination and root growth of Sinapis alba seeds. Bull Environ Contam Toxicol 52: 452-456

Fedtke C, Duke SO (2005) Herbicides. In: Hock B, Elstner EF (eds) Plant Toxicology, 4th edn. Marcel Dekker, New York, pp 247-330

Feng L, Wang L, Zhao Y, Song B (1996) Effects of substituted anilines and phenols on root elongation of cabbage seed. Chemosphere 32 : $1575-1583$

Fiskesjö G (1985) The Allium test as a standard in environmental monitoring. Hereditas 102:99-112

Fobbe R, Kuhlmann B, Nolte J, Preuss G, Skark G, Zullei-Seibert N (2006) Polar herbicides and metabolites. In: Reemtsma T, Jekel M (eds) Organic pollutants in the water cycle. Wiley, Weinheim, pp $121-153$
Gasiewicz TA (1991) Nitro compounds and related phenolic pesticides. In: Hayes WJ, Lawes ER (eds) Handbook of pesticides toxicology, vol 3. Academic, San Diego, pp 1191-1269

Gong P, Wilke BM, Strozzi E, Fleischmann S (2001) Evaluation and refinement of a continuous seed germination and early seedling growth test for the use in the ecotoxicological assessment of soils. Chemosphere 44:491-500

Gramatica P, Santagostino A, Bolzacchini E, Rindone B (2002) Atmospheric monitoring, toxicology and QSAR modelling of nitrophenols. Fres Environ Bull 11:757-762

Hansch C, Leo A, Taft RW (1991) A survey of Hammett substituent constants and resonance and field parameters. Chem Rev 91:165195

Hillis DG, Fletcher J, Solomon KR, Sibley PK (2011) Effects of ten antibiotics on seed germination and root elongation in three plant species. Arch Environ Contam Toxicol 60:220-232

Hulzebos EM, Adema DMM, Dirven-Van Breemen EM, Henzen L, Van Gestel V (1991) QSARs in phytotoxicity. Sci Total Environ 109110:493-497

Hutchinson TH, Shillabeer N, Winter MJ, Pickford DB (2006) Acute and chronic effects of carrier solvents in aquatic organisms: a critical review. Aquatic Toxicol 76:69-92

Jin C, Chen Q, Sun R, Zhou Q, Liu J (2009) Eco-toxic effects of sulfadiazine sodium, sulfamonomethoxine sodium and enrofloxacin on wheat, Chinese cabbage and tomato. Ecotoxicology 7:878-885

Kearney PC, Kaufman DD (1975) Phenols. In: Kearney PC, Kaufman DD (eds) Herbicides: chemistry, degradation and mode of action. Marcel Dekker, New York, pp 582-707

Lin D, Xing B (2007) Phytotoxicity of nanoparticles: Inhibition of seed germination and root growth. Env Poll 150:243-250

Ma Y, Kuang L, He X, Bai W, Ding Y, Zhang Z, Zhao Y, Chai Z (2010) Effects of rare earth oxide nanoparticles on root elongation of plants. Chemosphere 78:273-279

Manzo S, Rocco A, Carotenuto R, De Luca PF, Miglietta ML, Rametta G, Di Francia G (2011) Investigation of ZnO nanoparticles' ecotoxicological effects towards different soil organisms. Environ Sci Poll Res 18:756-763

Montvydiené D, Marčiulioniené D (2004) Assessment of toxic interactions of heavy metals in a multicomponent mixture using Lepidium sativum and Spirodela polyrrhiza. Environ Toxicol 19:351-358

Moore MT, Kröger R (2010) Effect of three insecticides and two herbicides on rice (Oryza sativa) seedling germination and growth. Arch Environ Contam Toxicol 59:574-581

Nolte J, Heimlich F, Graß B, Zullei-Seibert N, Preuß G (1995) Studies on the behaviour of dihalogenated hydroxybenzonitriles in water. Fres J Anal Chem 351:88-91

OECD (1984) Guidelines for testing of chemicals no.208, Terrestrial Plants, Growth Test. Organization for the Economic Cooperation and Development, Paris

OECD (2006) Guidelines for the testing of chemicals, terrestrial plant test: seedling emergence and seedling growth test. Organization for the Economic Cooperation and Development, Paris

Okumura Y, Koyama J, Takaku H, Satoh H (2001) Influence of organic solvents on the growth of marine microalgae. Arch Environ Contam Toxicol 41:123-128

Reynolds T (1977) Comparative effects of aliphatic compounds on inhibition of lettuce fruit germination. Ann Bot 41:637-648

Rodriguez-Ruiz A, Asensio V, Zaldibar B, Soto M, Marigómez I (2014) Toxicity assessment through multiple endpoint bioassays in soils posing environmental risk according to regulatory screening values. Environ Sci Pollut Res 21:9689-9708

Salizzato M, Pavoni B, Volpi Ghirardini A, Ghetti PF (1998) Sediment toxicity measured using Vibrio fischeri as related to the concentrations of organic (PCBs, PAHs) and inorganic (metals, sulphur) pollutants. Chemosphere 36:2949-2968 
Sawhney VK, Srivastava LM (1977) Comparative effects of cytochalasin B and colchicine on lettuce seedlings. Ann Bot 41:271-274

Siddiqui AH, Tabrez S, Ahmad M (2011) Validation of plant based bioassays for the toxicity testing of Indian waters. Environ Monit Assess 179:241-253

Tiquia SM (2010) Reduction of compost phytotoxicity during the process of decomposition. Chemosphere 79:506-512

Urrestarazu Ramos E, Vaes WHJ, Verhaar HJM, Hermens JLM (1998) Quantitative structure-activity relationships for the aquatic toxicity of polar and nonpolar narcotic pollutants. J Chem Inf Comput Sci 38:845-852

US EPA (1996) Ecological Effects Test Guidelines. OPPTS 850.4200. Seed Germination/Root Elongation Toxicity Test. US Environmental Protection Agency

US FDA (1987) Seed germination and root elongation, Environmental assessment technical guide No. 4.06. US Food \& Drug Administration, Center for Food Safety and Applied Nutrition, Center for Veterinary Medicine, U.S. Department of Health and Human Services, Washington

Valerio ME, García JF, Peinado FM (2007) Determination of phytotoxicity of soluble elements in soils, based on a bioassay with lettuce (Lactuca sativa L.). Sci Total Environ 378:63-66

Wain RL (1963) 3:5-dihalogeno-4-hydroxybenzonitriles: new herbicides with molluscicidal activity. Nature 200:28

Wang W (1987a) Chromate ion as a reference toxicant for aquatic phytotoxicity tests. Environ Toxicol Chem 6:953-960
Wang W (1987b) Root elongation method for toxicity testing of organic and inorganic pollutants. Environ Toxicol Chem 6:409-414

Wang W (1991) Literature review on higher plants for toxicity testing. Water Air Soil Poll 59:381-400

Wang WC, Freemark K (1995) The use of plants for environmental monitoring and assessment. Ecotoxicol Environ Saf 30:289-301

Wang X, Dong Y, Han S, Wang L (2000) Structure-phytotoxicity relationship: comparative inhibition of selected nitrogen-containing aromatics to root elongation of Cucumis sativus. Bull Environ Contam Toxicol 64:859-865

Wang X, Sun C, Gao S, Wang L (2001) Validation of germination rate and root elongation as indicator to assess phytotoxicity with Cucumis sativus. Chemosphere 44:1711-1721

Wang X, Yu J, Wang Y, Wang L (2002a) Mechanism-based quantitative structure-activity relationships for the inhibition of substituted phenols on germination rate of Cucumis sativus. Chemosphere 46:241-250

Wang X, Sun C, Wang Y, Wang L (2002b) Quantitative structure-activity relationships for the inhibition toxicity to root elongation of Cucumis sativus of selected phenols and interspecies correlation with Tetrahymena pyriformis. Chemosphere 46:153-161

Wang X, Wang Y, Chunsheng Y, Wang L, Han S (2002c) Mechanismbased quantitative structure-phytotoxicity relationships comparative inhibition of substituted phenols on root elongation of Cucumis sativus. Arch Environ Contam Toxicol 42:29-35

Zucconi F, Monaco A, Forte M, De Bertoldi M (1985) Phytotoxins during the stabilization of organic matter. In: Gasser JKR (ed) Composting of agricultural and other wastes. Elsevier, London, pp 73-85 